professional engagements, her doctoral studies at Columbia University, and her teaching and research in Texas and Virginia were shaped by and perceived through the magnifying glass of the contradictions of historical narratives and the inconsistencies and voids in the fabric of life and global transitions pertaining to past and present. She saw and understood the emotional link between our spaces of contrasting projections, similarities of fortune, and imaginary excavations of the plains of memory of living in communal utopias. I cherish the many letters, cards, and packages I received from her, our telephone conversations, and our professional and personal discussions! While teaching at Miami University, I was delighted to help arrange the Milka Bliznakov gift of rare books to Miami University's King Library.

As IAWA board advisor Kristine K. Fallon, FAIA, wrote about Bliznakov, "She was an educator who opened vistas for her students, as she has opened a view into the work and contributions of women in architecture for the international design community. She was personally excited to encounter new knowledge and new experiences and she communicated that inexhaustible intellectual zest to all." Board advisor Helga Schmidt-Thomsen added, "She was a great personality, a strong fighter, had faced so many struggles in her life and really was an exceptional character in her generation. IAWA is a great legacy, and we all will keep Milka in mind thankfully and with a smiling face." The IAWA honors her memory through the annual Milka Bliznakov Prize given to architects, scholars, and researchers for their research on women in architecture and related design fields. This research, in concert with the preservation efforts of the IAWA, helps bridge the gap in historical knowledge about women's professional achievements.

Milka Bliznakov was a strong, beautiful, and generous person, with a graceful sense of humor and a remarkable talent for overcoming hardships and realizing the most challenging aspirations. A gifted and inspiring teacher and an exceptionally caring individual who always championed human rights, she leaves behind a pioneering legacy that will continue to shine brightly for generations to come.

\author{
ANNA Sokolina \\ Executive Editor, Alternative Spaces \\ December 2010
}

\title{
Michael Confino, 1926-2010
}

Michael Confino, one of the greatest historians of eighteenth- and nineteenth-century Russia, came from a Bulgarian Sephardic family then living in Sofia, where he was born on 2 April 1926. As he loved to remember, before the war his family spent long months in France, and he was awarded the gold medal as the best student in Sofia's French lycée by Angelo Roncalli, the apostolic nuncio in the Balkans who was to become Pope John XXIII. Like other Bulgarian Jews, Confino survived the Shoah thanks to the Bulgarians' courageous behavior, and before emigrating to Israel in 1948, he attended the University of Sofia.

After serving the newly born state of Israel in various capacities, Confino studied at Hebrew University (1955-57) and then, by virtue of a French government scholarship, at the Sorbonne and the Sixième section of the École pratique des hautes études (1957-59), the nucleus of Fernand Braudel's École des hautes études.

Confino thus found himself at the very heart of the Annales' historiographic revolution, in which he actively participated, creating his own original place by virtue of his capacity to combine social, economic, and intellectual history. Acutely aware of the importance of comparative history, of the collective psychology of social groups, and of structures, Confino was at the same time attuned to the history of minorities and individuals. This combination was to give his writings that extraordinary capacity to "breathe" and that extremely rich texture that still distinguish them even among the works of other major historians.

A professor at Hebrew University (1959-70), whose Department of Russian Studies he founded, Confino rapidly established himself as perhaps the world's leading specialist 
on the Russian countryside in the nineteenth century and a most sophisticated znatok of rural Russia. Two of his books must be mentioned: Domaines et seigneurs en Russie vers la fin $d u$ XVIII siècle (1963) and Systèmes agraires et progrès agricole (1969). I still vividly remember my impression when I first read them, my excitement at meeting a most lively, intelligent, and sophisticated mind, an impression so strong as to make me think that perhaps such intelligence was wasted on what might seem "minor" topics.

Confino thus became one of the pioneers of the pleiade that reshaped our knowledge, not only of the Russian and Soviet countryside, but of peasant societies in general: Moshe Lewin and Theodore Shanin, who followed him in France; Basile Kerblay and Daniel Thorner, who in the mid-1960s "rediscovered" Aleksandr Chaianov; and V. P. Danilov, who was then studying the Soviet village both before and after Iosif Stalin's raskrest'ianivanie. In addition to giving us what still remains the best and most intelligent overview of rural life in late imperial Russia, an overview always capable of contextualizing that life in the wider European framework, Confino then elaborated the "equilibrium analysis" paradigm in agrarian development, which influenced rural scholars in many fields and countries.

In 1970 Confino moved to the University of Tel Aviv, where he founded the Russian History Studies Program, out of which the Cummings Center developed. Confino held the Samuel Rubin Chair of Russian and East European History and Civilization. In spite of the many invitations, the years spent teaching or as a fellow in major American and European universities and institutions (Chicago, Harvard, Stanford, Duke, Columbia, the Woodrow Wilson International Center, the National Humanities Center in North Carolina, Oxford, the Istituto Italiano per gli Studi Filosofici, the Centre national de la recherche scientifique, and of course, and often, the École), and his many students, friends, and admirers on both sides of the Atlantic, Confino chose to live and teach in Israel, and he remained at the University of Tel Aviv until his retirement. In 1993 he was honored with the Israel Prize, the highest honor bestowed by the Israeli state; in 1994 he was elected to the Israeli Academy of Sciences; and in 2003 he was awarded the Emet Prize.

Confino's keen mind allowed him to make fundamental contributions to our understanding of other aspects of imperial Russia as well as to the anarchist movement and the Russian intelligentsia, and he was among the first to underline its "nongenerational" evolution. He also greatly enriched our knowledge of these phenomena by discovering and editing important new documents, as in Daughter of a Revolutionary: Natalie Herzen and the Bakunin-Nechayev Circle (1973) and Anarchistes en exil: Correspondance inédite de Pierre Kropotkine à Marie Goldsmith, 1897-1917 (1995).

Confino was also a profound, and at times even a radical, critic of our métier, of its dead ends as well as of its ideological or just simplistic and superficial pitfalls (I deem his 1994 essay "Present Events and the Representation of the Past," published in Cahiers $d u$ monde russe, an unsurpassed model). Yet he always remained a charming, supportive, and farsighted man. I had the good fortune to have him as an informal teacher first and as a cherished and beloved friend later on, and I came to think of him as the closest embodiment of wisdom I encountered in my life.

What especially impressed me was his capacity to reflect upon his own limits and misconceptions, and his keen awareness of the impediments that ageing brought to his, still extraordinary, abilities. Also in this perspective, he was a true historian, capable of seeing the problems and potentials of each period, including those in his own life, and refusing to reduce phenomena and events, including his own mind and personality, to an ahistorical dimension. He once told me that old age was suited for erudite critical editions of texts and for reflections on our trade. Considering the powerful essays he was writing, this seemed a joke, yet it was a true, and profound, observation that signalled his capacity to always give the best he could. It was also yet another proof of his passion for documents, archives, and critical editions, as well as of his multifaceted interests, which led him to chair for many years, after the death of his friend Franco Venturi (of whom he sketched a splendid portrait), the scientific council of the series Dokumenty sovetskoi istorii (1993-).

In an interview published in Kritika 9, no. 2 (Spring 2008), Confino recounted something about his life, as well as his ideas about what it means to be a historian. A collection of his essays, Russia before the "Radiant Future": Essays in Modern History, Culture, and Society, 
which he was preparing shortly before his death, will be published in 2011 by Berghahn Press. Confino died in Israel on 16 June 2010.

ANdrea Graziosi

Università di Napoli Federico II, Italy

November 2010

\section{Il'ia Zakharovich Serman, 1913-2010}

Il'ia Zakharovich Serman, a noted scholar of Russian literature, died in Jerusalem on 9 October 2010. Born on 22 September 1913, Il'ia Zakharovich did his undergraduate work at Leningrad University, graduating in 1939. There he drew inspiration from the gifted literary historian G. A. Gukovskii. In June 1941, immediately following the German invasion, Il'ia Zakharovich left his first teaching position to work on the daily radio broadcast "This Is Leningrad Speaking." In December 1941 he joined the Red Army and fought on the Volkhov front outside Leningrad. Discharged in 1942 after suffering from shell shock, I'ia Zakharovich spent the remainder of the war in Tashkent, where his mother and stepfather had evacuated to escape the Leningrad blockade. In Tashkent he wrote and defended his PhD (kandidat) dissertation on Fedor Dostoevskii. In 1943, also in Tashkent, he met and married Ruf' Aleksandrovna Zernova, who went on to a distinguished career of her own as a writer.

In 1949, during the "anticosmopolitanism" campaign of the late Stalin era, Il'ia Zakharovich and Ruf' Aleksandrovna were arrested for "anti-Soviet propaganda" and sentenced to ten years at hard labor. A device that authorities had placed in their apartment recorded the concerns they had expressed over the antisemitism that had become such a dominant feature of state policy in the late Stalin years. A second trial increased Il'ia Zakharovich's sentence to twenty-five years at hard labor. After a journey of some nine months, he arrived at Kolyma, where he remained until his release (and amnesty) in July 1954.

His return to Leningrad at the outset of the thaw, while an obvious relief, did not guarantee an easy life. Between 1954 and 1956, without regular employment, I'ia Zakharovich managed to eke out a living through his writing. In 1956, he gained a secure appointment as a mladshii nauchnyi sotrudnik at the Institute for Russian Literature (Pushkinskii Dom) in Leningrad, where he joined the eighteenth-century sector. Here, over twenty years, he enjoyed a productive career, and his books and articles brought him increasing scholarly recognition.

In the spring of 1969, Il'ia Zakharovich successfully defended his advanced doctorate at Pushkinskii Dom. His dissertation explored the rise of a new, secular Russian literature in the eighteenth century, and he focused on the role that poets such as Antioch Kantemir, Aleksandr Sumarokov, Vasilii Trediakovskii, Mikhail Lomonosov, and Gavrila Derzhavin played in creating and developing that literature. While best known for his writing on the eighteenth century, Il'ia Zakharovich also had a specialist's knowledge of nineteenth- and twentieth-century Russian literature. As part of his duties at Pushkinskii Dom, he edited individual volumes in the larger collected works of Nikolai Leskov, Dostoevskii, and others, providing these volumes with substantial introductions, annotations, and explanatory material.

During the 1960s and 1970s, Il'ia Zakharovich and Ruf' Aleksandrovna extended their hospitality and friendship to numerous western scholars who were doing research in Leningrad. Although they were not unique in doing so, the openness with which they welcomed foreigners outside official channels was remarkable, and not without risk to themselves. In their company - and that of their children, Nina and Mark-one encountered a world in which the vitality and existential significance of Russian literature formed the warp and woof of the household.

In 1976, after granting written permission for his daughter, Nina, to emigrate from the Soviet Union, Il'ia Zakharovich was dismissed from his job at Pushkinskii Dom. Soon afterwards, he and Ruf' Aleksandrovna left the Soviet Union for Israel, where he joined the faculty of Hebrew University in Jerusalem. Emigration, which is inevitably disruptive and fraught with practical problems, may also bring new opportunities. Il'ia Zakharovich 